\title{
UDC 669.054.8
}

\section{THERMODYNAMIC PARAMETERS OF PROCESSING COBALT-CONTCAINING ORES AND OF IVESTIGATION OF CONDITIONS OF SEPARATION COBALT FROM SOLUTION}

\author{
N.V.Yusifova \\ M.Nagiyev Institute of Catalysis and Inorganic Chemistry, NAS of Azerbaijan \\ naile.yusifova@inbox.ru \\ Received 15.04.2019
}

\begin{abstract}
Kinetics of separation of Co by dissolution of cobalt ores was studied. Using of methods chemical analysis decomposition of cobalt, iron, calcium, manganese and magnesium oxides to simple chlorides with thermal consequence at interacting with ammonium chloride and forming ammonium chloride complexes was confirmed. Optimum yield of cobalt makes up $94 \%$ at $300^{\circ} \mathrm{C}$ for $160 \mathrm{~min}$. To define the mechanism of the process results of thermogravimetric and X-ray phase analysis methods were used. Free energy values of chlorination of cobalt compounds with ammonium chloride were calculated. Change of Gibbs energy value depending on the temperature was calculated. As seen from calculations obtaining of compound $\mathrm{CoCl}_{2}$ is possible from thermodynamic. Separation condition of cobalt and accompanying elements from solutions depending on $\mathrm{pH}$ by precipitation was studied.
\end{abstract}

Keywords: cobalt, ammonium chloride, ore, free energy, thermodynamics, precipitation.

doi

\section{Introduction}

Cobalt ores have different mineralogical and chemical compositions and are manycolored. In ores amount of cobalt may change in a wide range - from one hundred per cent -to several per cent. When amount of cobalt is $0.15 \%$ or less in non-oxidized complex ores (with sulfide and arsenyl), the production of it is economically profitable. In Azerbaijan the main reserves of cobalt are in Southern Dashkasan deposit. The main mineral of this deposit is cobaltite. In samples the red cobalt mineral can be also seen. Maximum yield of cobalt to solution depends on easy dissolution of its mineral in water or other solvents, i. e., cobalt $\mathrm{Co}^{3+}$ in mineral should be brought to maximum soluble salt form. The reason of partial extraction of cobalt from ore is weak dissolution of its minerals in water, acid and alkali solutions. To bring cobalt to maximum soluble form, crystal cell of its minerals in ore should be decomposed. Ore sample is activated in two ways: by thermal decomposing in inert medium and oxidizing with atmospheric air. As seen from mineralogical composition of ore most of minerals consist of solid silicates (clinochlorine, andradite) $[1,2]$. Since enrichment of this mineral by physical methods is impossible we have used chemical enrichment technique. Recent researches of chemists and technical-engineers on complex processing of mineral raw materials are of great interest [3-8]. Therefore, authors preferred to use ammonium chloride to extract valuable metals from different ore and processing products.

Analysis of our work [1] showed that when roasting primary materials by mixing them with ammonium chloride positive changes are observed in dissolution mechanism of $\mathrm{Fe}$, $\mathrm{Mn}, \mathrm{Mg}, \mathrm{Zn}$ and Co. Essence of the technology is that when valuable non-ferrous metals $(\mathrm{Fe}$, $\mathrm{Mn}, \mathrm{Mg}, \mathrm{Zn}$ and $\mathrm{Co}$ ) in ore and concentrates are roasted with ammonium chloride intermediate chlorammonium complexes are formed. If heating continues the complexes decompose into relevant soluble chloride salts and gaseous $\left(\mathrm{NH}_{3}, \mathrm{HCl}\right)$ solutions. It is interesting that valuable non-ferrous metals in raw material form complexes which dissolve with $\mathrm{NH}_{4}^{+}$, but mixed metals iron, manganese, calcium do not form complexes under this condition. Ammonium chloride does not interact with silicium and aluminum oxides. Ammonia complexes of iron, zinc, cobalt and manganese have different resistance constants. Using this property they can be separated by boiling the solution and destroying complexes. Unlike copper, zinc and nickel ammonia complex $\left[\mathrm{Co}\left(\mathrm{NH}_{3}\right)_{4}\right]^{2+}$ of divalent cobalt is easily decomposed and the com- 
plex of trivalent cobalt is more stable than complex compounds of these metals [3]. Using this property and boiling the solution cobalt can be kept in solution and other ions can be kept in precipitate. Unlike chloride acid ammonium chloride differs in selectivity and is not a hazardous substance.

\section{Experimental part}

The studied Dashkesen Cobalt ore is polymineral ore. According to the results of Xray and mineralogical analysis methods is ore contains the following minerals: cobaltite, erythrite, clinochlore, andradite, $\alpha$-quartz, hematite, aluminum phosphide. Under the microscope, the major rock-forming minerals such as aluminosilicates (clinochlore, andradite) are observed in the form of large and small grains of irregular shape. Cobaltite in polished sections is characterized by its weak anisotropy effects, it has a pinkish-brown colour. Depending on its location it can be found in the cracks among garnet skarns, sometimes it is intergrown with safflorite accompanied with pyrite. From the results of mineralogical analysis investigated that cobalt ore is also high siliceous aluminum raw material which contains: clinochlore $44.2 \%$, andradite $-23.3 \%$, $\alpha$-quartz $-11.2 \%$, aluminum phosphide $-2.2 \%$. Despite the low aluminum content (4.5-7.6\%), the presence of other valuable components such as $\mathrm{Mg}, \mathrm{K}, \mathrm{Ti}$, $\mathrm{Mn}, \mathrm{Cr}$. Revealed is complexity of this type ore processing is that their enrichment process is difficult associated with presence of both sulfoarsenic and oxidized minerals and interaction their germination and also presence of other metals and impurities. Dashkesen cobalt ore has the following average of chemical composition (in terms of oxide) (mass\%): $\mathrm{Na}_{2} \mathrm{O}-1.48 ; \mathrm{MgO}-$ 5.65; $\mathrm{Al}_{2} \mathrm{O}_{3}-14.29 ; \mathrm{SiO}_{2}-44.64 ; \mathrm{SO}_{3}-0.85 ; \mathrm{K}_{2} \mathrm{O}-$ 1.32; $\mathrm{CaO}-7,19 ; \quad \mathrm{As}_{2} \mathrm{O}_{3}-5.20 ; \quad \mathrm{Fe}_{2} \mathrm{O}_{3}-12,93$, $\mathrm{MnO}-0,43, \mathrm{TiO} 2-0,54$. Established that the $\mathrm{CoO}$ content in the ore is in the $3.58-5.48 \%$ range

Before processing ore with ammonium chloride cobalt mineral in it should be activated thermally decomposed. Results of thermal analysis are given [1]. As seen from thermogram at temperature up to $760^{\circ} \mathrm{C}$ serious change is not observed in the material. In X-ray phase analy- sis of material obtained at $850^{\circ} \mathrm{C}$ intensities typical for $\mathrm{CoS}$ and CoAs are observed. It is supposed that cobalt mineral in ore is thermally decomposed by the following equation:

$$
\mathrm{CoAsS} \stackrel{850^{\circ} \mathrm{C}}{\longrightarrow} 4 \mathrm{CoS}+4 \mathrm{CoAs}+\mathrm{As}_{4} \mathrm{~S}_{4} .
$$

Cobalt ore was roasted in inert, oxidizing and ammonium chloride in furnaces with horizontal tube. Raw cobalt ore or mixture of ammonium chloride with a burnt obtained from thermal decomposition is added into quartz tube with diameter of $40 \mathrm{~mm}$, and furnace was heated up to given temperature and roasted. After the experiment roasted products were taken out of the furnace and cooled at room temperature. The burnt was weighed in a balance and its composition was analyzed on $\mathrm{Fe}, \mathrm{Co}, \mathrm{As}, \mathrm{Cu}$, $\mathrm{Al}$ and other components. Gas $\left(\mathrm{NH}_{3}\right)$ obtained in the experiments with ammonium chloride were adsorbed with $5 \%$ chloride acid. Cooled solution was dissolved at $80^{\circ} \mathrm{C}$ for an hour with water in a magnetic mixer. Obtained solution and dry residue (cake) was analyzed on the above mentioned elements.

\section{Results and discussion}

Thermal processing of "Ore- $\mathrm{NH}_{4} \mathrm{Cl}$ " mixture was carried out. To define the mechanism of the process thermographic and X-ray phase analyses methods were used [1]. The reactions of thermal oxidation and chlorination reaction of cobalt ore with ammonium chloride on cobalt can be expressed by the following chemical equation 1) thermal decomposition of cobalt:

$$
\begin{aligned}
& 2 \mathrm{CoS}+3 \mathrm{O}_{2} \longrightarrow 2 \mathrm{CoO}+2 \mathrm{SO}_{2}, \\
& \mathrm{CoS}+4 \mathrm{NH}_{4} \mathrm{Cl} \stackrel{280^{\circ} \mathrm{C}}{\longrightarrow}\left(\mathrm{NH}_{4}\right)_{2} \mathrm{CoCl}_{4}+2 \mathrm{NH}_{3}+\mathrm{H}_{2} \mathrm{~S}, \\
& \mathrm{CoO}+2 \mathrm{NH}_{4} \mathrm{Cl}=\mathrm{CoCl}_{2}+2 \mathrm{NH}_{3}+\mathrm{H}_{2} \mathrm{O}, \\
& \mathrm{CoO}+2 \mathrm{HCl}=\mathrm{CoCl}_{2}+\mathrm{H}_{2} \mathrm{O}, \\
& \left(\mathrm{NH}_{4}\right)_{2} \mathrm{CoCl}_{4} \stackrel{310^{\circ} \mathrm{S}}{\longrightarrow} \mathrm{CoCl}_{2}+2 \mathrm{NH}_{3}+2 \mathrm{HCl} .
\end{aligned}
$$

During chlorination of $\mathrm{CoO}$ and $\mathrm{CoS}$ with $\mathrm{NH}_{4} \mathrm{Cl}$ at $273-600 \mathrm{~K}$ the values of isobarthermal potentials of possible reactions were calculated using Temkin-Schwarzman's equation:

$$
\Delta G_{T}=\Delta H_{298}^{0}-T \Delta S_{298}^{0}-T\left(\mathrm{M}_{0} \Delta a+\mathrm{M}_{1} \Delta b+\mathrm{M}_{2} \Delta c\right) .
$$


Thermodynamic properties of substances $\left(\Delta \mathrm{H}, \Delta C_{p}, S_{p}\right)$ in the calculations were taken from reference book [9].

Table 1 shows calculated values of the change of Gibbs energy value of chlorination reactions of $\mathrm{CoO}$ and $\mathrm{CoS}$ with $\mathrm{NH}_{4} \mathrm{Cl}$ depending on temperature.

Table 1.Calcualted values of free energies of chlorination cobalt compounds with ammonium chloride

\begin{tabular}{|l|c|c|c|}
\hline \multirow{2}{*}{ Reactions } & \multicolumn{3}{|c|}{$\Delta G_{T}, \mathrm{kC} / \mathrm{mol}$} \\
\cline { 2 - 4 } & $298 \mathrm{~K}$ & $400 \mathrm{~K}$ & $600 \mathrm{~K}$ \\
\hline $\mathrm{CoO}+\mathrm{NH}_{4} \mathrm{Cl}$ & 84.4 & 27 & -21.47 \\
\hline $\mathrm{CoS}+\mathrm{NH}_{4} \mathrm{Cl}$ & 232 & 187 & 100.9 \\
\hline $\mathrm{CoO}+\mathrm{HCl}$ & -43.21 & -71.932 & -98.89 \\
\hline
\end{tabular}

As calculations show chlorination of cobalt oxide occurs faster and more rapidly than cobalt disulfide, i.e. production of $\mathrm{CoCl}_{2}$ is thermodynamically possible. For full characterization of the peaks observed in effects relevant to different temperatures on thermogram of Ore- $\mathrm{NH}_{4} \mathrm{Cl}$ mixture the samples were studied using $\mathrm{X}$-ray phase and IR spectroscopic methods.

Comparison of X-ray analysis showed that the intensity of the minerals in the initial spleen changes partly after chlorination. The peaks which are typical for $\left(\mathrm{NH}_{4}\right)_{2} \mathrm{CoCl}_{4}, \mathrm{NH}_{4} \mathrm{CoCl}_{3}$, $\mathrm{CoCl}_{2} \mathrm{NH}_{4} \mathrm{Cl}$ are observed in the material after chlorination. The composition of the chlorinated complex was confirmed using chemical analysis method.

Mass percent of $\mathrm{Co}: \mathrm{Cl}: \mathrm{NH}_{4}$ in the complex compound formed from $\mathrm{CoO}$ and $\mathrm{NH}_{4} \mathrm{Cl}$ was 17.7:62.1:20.8.

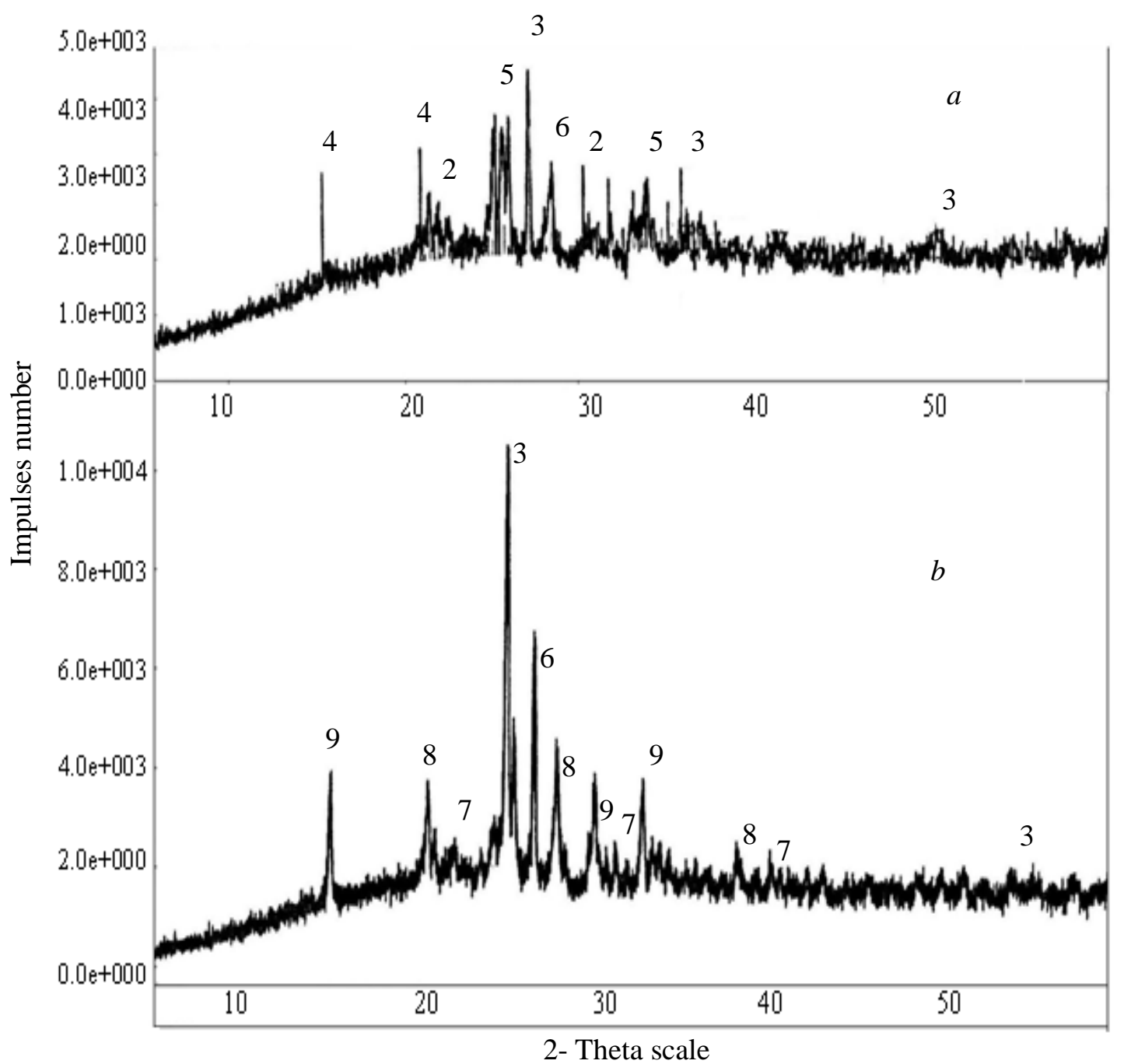

Fig. 1. The initial oxidized cobalt ore $(a)$ and its mix with $\mathrm{NH}_{4} \mathrm{Cl}(1: 1)$ at $265^{\circ} \mathrm{C}$ is given X-ray of processing products $(b)$. In the X-ray: 1 - andradite, 2 - hematite, 3 - quartz, 4 - clinochlore, 5 - cobaltite, 6 albite, $7-\mathrm{CoCl}_{2}, 8-\left(\mathrm{NH}_{4}\right)_{2} \mathrm{CoCl}_{4}, 9-\mathrm{CoCl}_{2}\left(\mathrm{H}_{2} \mathrm{O}\right)_{2}$. 
Calculated molar ratio $\frac{17.7}{58.93}: \frac{62.1}{35.5}: \frac{20.8}{18}=$ $0.3: 1.75: 1.155=1: 5.83: 3.85=1: 6: 4$ conforms to the compound $\mathrm{CoCl}_{2} \cdot 4 \mathrm{NH}_{4} \mathrm{Cl}$.

According to the results of experiments interaction mechanism of cobalt dioxide with ammonium chloride can be shown by the following conversions:

$$
\begin{aligned}
& \mathrm{CoAsS} \stackrel{-\mathrm{CoAs}}{\longrightarrow} \quad \mathrm{CoS} \underset{-\mathrm{SO}_{2}}{\stackrel{\mathrm{O}_{2}}{\longrightarrow}} \mathrm{CoO} \stackrel{+\mathrm{NH}_{4} \mathrm{Cl}}{\longrightarrow} \\
& \rightarrow \mathrm{CoCl}_{2} \cdot 4 \mathrm{NH}_{4} \mathrm{Cl} \stackrel{181^{\circ} \mathrm{C}}{\longrightarrow}\left(\mathrm{NH}_{4}\right)_{3} \mathrm{CoCl}_{5} \rightarrow \\
& \underset{\mathrm{NH}_{4} \mathrm{Cl}}{\stackrel{+}{\longrightarrow}}\left(\mathrm{NH}_{4}\right)_{2} \mathrm{CoCl}_{4} \underset{\left.-\mathrm{NH}_{3}, \mathrm{NCl}\right)}{\stackrel{260^{\circ} \mathrm{C}}{\longrightarrow}} \\
& \rightarrow \mathrm{NH}_{4} \mathrm{CoCl}_{3} \underset{+\mathrm{NH}_{4} \mathrm{Cl}}{\stackrel{309^{0} \mathrm{C}}{\longrightarrow}} \mathrm{CoCl}_{2} \text {. }
\end{aligned}
$$

Basing on these results we may conclude that $\mathrm{NH}_{4} \mathrm{Cl}$ reagent can be advisable and useful for processing oxidized cobalt ore. With this reagent we may transform oxidized cobalt in ore into chlorinated salt form at $200-320^{\circ} \mathrm{C}$ $[10,11]$. Researches showed that ammonium chloride can be used in processing of cobalt ores. Ammonium chloride is also broken at $338^{\circ} \mathrm{C}$. As a result of the interaction of the oxide in the ore with ammonium chloride ammonium chloromethylates are formed.

$\mathrm{NH}_{4} \mathrm{Cl} \stackrel{338^{\circ} \mathrm{C}}{\longrightarrow} \mathrm{NH}_{3}+\mathrm{HCl}$,

$\mathrm{CoO}+2 \mathrm{NH}_{4} \mathrm{Cl}=\mathrm{CoCl}_{2}+2 \mathrm{NH}_{3}+\mathrm{H}_{2} \mathrm{O}$,

$\mathrm{CoO}+2 \mathrm{HCl}=\mathrm{CoCl}_{2}+\mathrm{H}_{2} \mathrm{O}$,

$\mathrm{Fe}_{2} \mathrm{O}_{3}+6 \mathrm{NH}_{4} \mathrm{Cl}=2 \mathrm{FeCl}_{3}+6 \mathrm{NH}_{3}+\mathrm{H}_{2} \mathrm{O}$,

$\mathrm{Fe}_{2} \mathrm{O}_{3}+6 \mathrm{HCl}=2 \mathrm{FeCl}_{3}+3 \mathrm{H}_{2} \mathrm{O}$,

$\mathrm{MnO}+2 \mathrm{NH}_{4} \mathrm{Cl}=\mathrm{MnCl}_{2}+\mathrm{NH}_{3}+\mathrm{H}_{2} \mathrm{O}$,

$\mathrm{MnO}+2 \mathrm{HCl}=\mathrm{MnCl}_{2}+\mathrm{H}_{2} \mathrm{O}$,

$\mathrm{SiO}_{2}+\mathrm{NH}_{4} \mathrm{Cl}$ - the reaction does not.

For comparison, cobalt(III) oxides were used in the experiments. $2 \mathrm{~g} \mathrm{Co}_{2} \mathrm{O}_{3}$ with $4 \mathrm{~g}$ $\mathrm{NH}_{4} \mathrm{Cl}$ at $260,280,320^{\circ} \mathrm{C}$ burned.

At $260^{\circ} \mathrm{C}\left(\mathrm{NH}_{4}\right)_{3} \mathrm{CoCl}_{5}$ complex, and at $280^{\circ} \mathrm{C} \mathrm{NH} \mathrm{CoCl}_{3}$, $\left(\mathrm{NH}_{4}\right)_{2} \mathrm{CoCl}_{4}$ complexes are formed. To find out the mechanism of the pro- cess we used the following analysis methods: thermography, X-ray phase and IR spectroscopy. The product of the interaction of ammonium chloride with a candle of cobalt ore, obtained at $3000^{\circ} \mathrm{C}$, was studied by IR spectroscopy (Figure 2). The IR spectrum proves the presence of bond oscillations: $\left[\mathrm{CoCl}_{4}\right]^{2-}-$ the chlorammonium complex at $1754.97 \mathrm{~cm}^{-1}(a), 1731.96 \mathrm{~cm}^{-1}(b)$.

Further works were performed on the precipitation of cobalt and accompanying elements in solutions. Cobalt can be found in ores, minerals, alloys and other industrial and natural materials together with iron, nickel, magnesium, copper, chromium, vanadium and other elements. Cobalt(III) is located in analytic cation group. Determination of $\mathrm{pH}$ of solution in hydrometallurgy processes in the processing of ore is important. At different values of $\mathrm{pH}$ separation of valuable components from each other occurs. Precipitation was carried out using ammonia water, iron $\mathrm{pH}=4.5 \mathrm{Fe}(\mathrm{III})$ is separated in solution in a form of $\mathrm{Fe}(\mathrm{OH})_{3}$ hydroxide. Since aluminum has atmospheric property its precipitation occurs at $\mathrm{pH}=4.5-6, \mathrm{pH}=8-8.5 \mathrm{Co}^{2+}$ ion is separated in the form of precipitate and $\mathrm{Mn}^{2+}$ ions is precipitated in the form of $\mathrm{Mn}(\mathrm{OH})_{2}$; manganese, magnesium, calcium are precipitated at $\mathrm{pH} 8.5$.

During dissolution cations formed in solutions were exposed to stepwise hydrolysis and form hydrocomponents by the following scheme:

$$
\begin{aligned}
& \mathrm{Me}^{n+}+\mathrm{H}_{2} \mathrm{O} \longrightarrow \mathrm{Me}(\mathrm{OH})^{+(n-1)}+\mathrm{H}^{+} ; \\
& \mathrm{Me}(\mathrm{OH})^{+(n-1)}+\mathrm{H}_{2} \mathrm{O} \longrightarrow \mathrm{Me}(\mathrm{OH})_{2}^{+(n-2)}+\mathrm{H}^{+} ; \\
& \mathrm{MeOH}_{n}^{0}+\mathrm{OH}^{-} \longrightarrow \mathrm{Me}(\mathrm{OH})_{n+1}^{-} .
\end{aligned}
$$

Metal ions $\mathrm{Fe}^{2+}, \mathrm{Fe}^{3+}, \mathrm{Co}^{2+}, \mathrm{Mn}^{2+}$ are in different ion and molecular forms depending on density and $\mathrm{pH}$. Results of precipitation are given in the following Table 2.

As the results form the table show selective precipitation of metals occurs. Aluminum and iron begin precipitating at $\mathrm{pH}$ 4.5. Thicker precipitate appears during precipitation of magnesium at $\mathrm{pH}$ 9.5-11. In the range of $\mathrm{pH} 7-9.5$ the complex precipitate of cobalt and manganese is formed. 


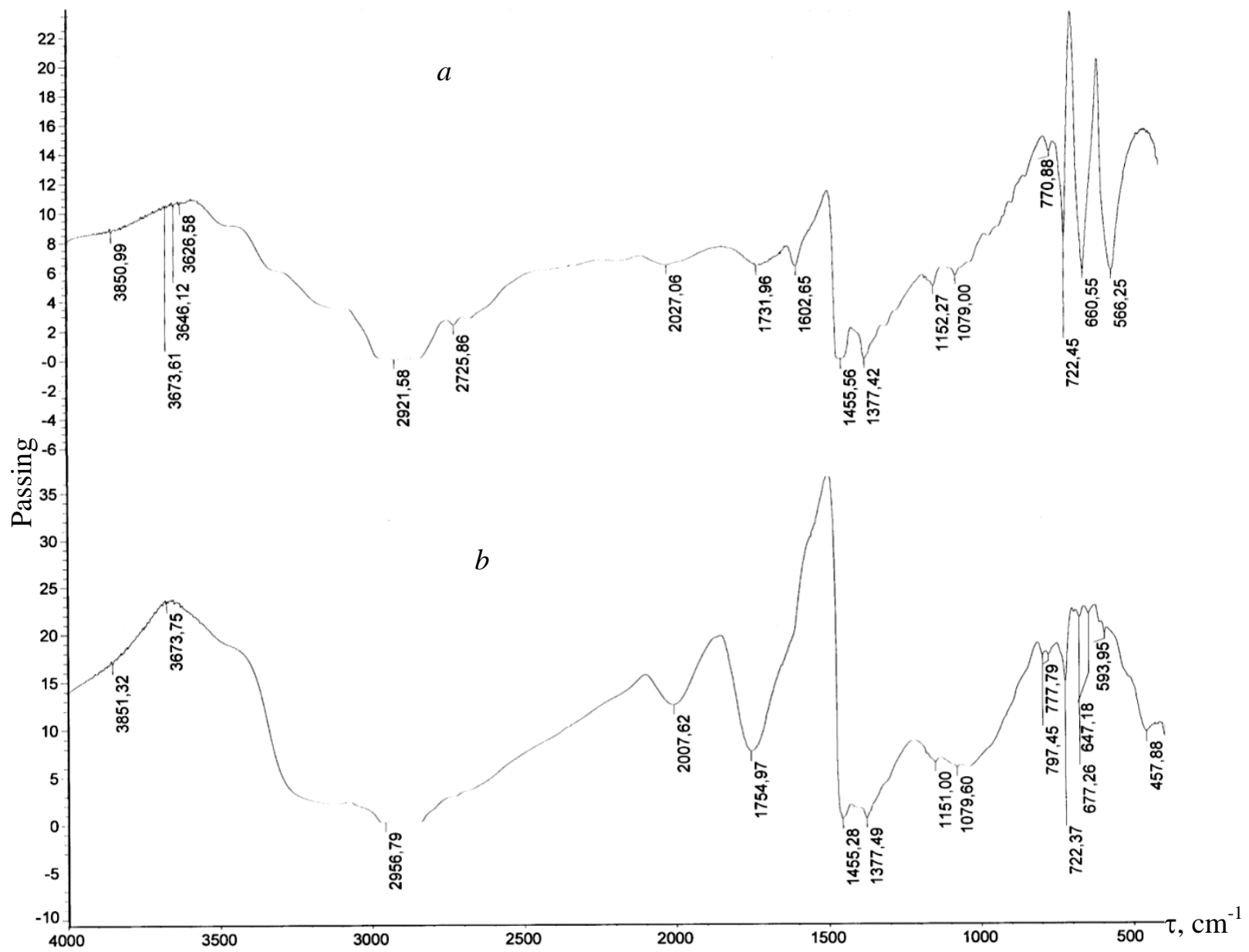

Fig.2. $a$ - product of the interaction of ore and $\mathrm{NH}_{4} \mathrm{Cl}, b-\mathrm{IR}$ spectrum of the of the interaction of $\mathrm{CoO}$ and $\mathrm{NH}_{4} \mathrm{Cl}$. The research showed that annealing process with ammonium chloride can be used in the processing of cobalt ore. The developed method differs by its in effectiveness and can be used for extraction of Co from sulfoarsenide ores.

Table 2. Results of precipitation depending on $\mathrm{pH}$

\begin{tabular}{|c|c|c|c|c|c|}
\hline \multirow[t]{2}{*}{$\mathrm{pH}$} & \multicolumn{5}{|c|}{ Yield, $\%$} \\
\hline & $\mathrm{Al}$ & $\mathrm{Fe}$ & Co & $\mathrm{Mn}$ & $\mathrm{Mg}$ \\
\hline 4 & 6.73 & 11.71 & - & - & - \\
\hline 4.5 & 43.29 & 29.43 & - & - & - \\
\hline 5 & 51.66 & 14.71 & 6.54 & 5.20 & 2.18 \\
\hline 5.5 & 4.73 & 49.33 & 0.27 & - & - \\
\hline 6 & 0.171 & 9.52 & - & - & - \\
\hline 6.5 & 0.037 & 0.00008 & - & - & - \\
\hline 7 & & & 22.25 & - & - \\
\hline 7.5 & & & 32.70 & - & 8.46 \\
\hline 8 & & & 21.25 & 8.80 & 2.51 \\
\hline 8.5 & & & 16.35 & 14.09 & 5.02 \\
\hline 9 & & & 0.58 & 30.81 & 2.18 \\
\hline 9.5 & & & 0.60 & 33.45 & 25.69 \\
\hline 10 & & & & 6.25 & 14.21 \\
\hline 10.5 & & & & 1.33 & 35.81 \\
\hline 12.5 & & & & 0.008 & - \\
\hline Total yield & 99.97 & 90.48 & 99.94 & 99.99 & 99.80 \\
\hline
\end{tabular}




\section{Conclusion}

Free energy values of chlorination of cobalt compounds with ammonium chloride were calculated. Calculated values of the change of Gibbs energy value depending on the temperature were given. As seen from the calculations obtaining of compound $\mathrm{CoCl}_{2}$ is thermodynamically possible.

\section{References}

1. Iusifova N.V., Geidarov A.A., Pashadzhanov A.M., Aliev I.I. Poluchenie kobalta iz sulfoarsenidnykh rud ispolzovaniem protcessov obzhiga s khloridom ammoniia i vyshchelachivaniia. Mezhdunar. zhurn. pricl. i fundament. issledovanii. 2018. № 1. S. 58-63.

2. Iusifova N.V., Geidarov A.A., Pashadzhanov A.M. Kobaltovoe mestorozhdenie Dashkesana. Iiulskie nauchnye chteniia. Sb. nauch. tr. po mater. Mezhdunar. nauchno-praktich. konf. Smolensk. 31 iiulia 2017. S. 118.

3. Mingzhu Zhanq, Guocai Zhu, Yuna Zhao, Xiujuan Feng. A study of recovery of copper and cobalt from copper-cobalt oxide ores by ammonium salt roasting. Hydrometallurgy. 2012. V. P. 129-130. P. 140-144.

4. Zhatkanbaev E.E, Zhabykbaev V.G, Maltykbaeva A.T. Pirmatov E.A, Munusheva A.S. Sposob pererabotki kobaltsoderzhashchikh promproduktov $\mathrm{s}$ ispolzovaniem ammiako-soderzhashchikh reagentov. Gornoinform. analit. biulleten. 2008. Seminar № 19. S. 59-62.

5. Andreev A.A., Diachenko A.N., Kraidenko R.I. Pererabotka okislennykh nikelevykh rud s primeneniem khlorida ammoniia. Him. tekhnol. 2010. T. 2. № 2. S. 91-96.

6. Diachenko A.N., Kraidenko R.I. Pererabotka okisdno-sulfidnykh mednykh rud s pomoshchiu khlorida ammoniia. Izv. VUZov. Tcvetnaia metallurgiia. 2010. № 5. S. 3-6.

7. Mingzhu Zhang, Guoca Zhu., Yuna Zhao, Xiujuanfeng. A study of recovery of copper and cobalt from copper-cobalt oxide ores by ammonium salt roasting. Hydrometallurgy. 2012. V. 129-130. P. 144.

8. Rashid K. Nadirov, Leila I. Syzdykova, Aisulu K. Recovery of value metals from copper smelter slag by ammonium chloride treatment. Int. J. Mineral Processing. 2013. V. 124. P. 145-149.

9. Riabin V.A., Ostroumov M.A., Svit T.F. Termodinamicheskie svoistva veshchestv. Spravochnik. L.: Himiia. 1977. 392 c.

10. Chunaeva V.D., Malkova A.S., Muldagolieva R.A., Pashinkin A.S. Teploemkost i termodinamicheskie funktcii kobaltina i monoarsenida kobalta. Kompleksnoe ispolzovanie mineralnogo syria. 1992. .№ 8. C. 86-89.

11. Makhmudov A.I. Mineralogiia kobaltovykh rud. M.: Nedra. 1982, $234 \mathrm{~s}$.

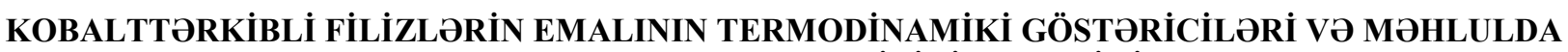 KOBALTIN AYRILMA ŞəRAITININ TODQIQI \\ N.V.Yusifova}

Kobaltlı filizlərin həllolması metodu ilə Co ayrılmasının kinetikası tədqiq edilmişdir. Kimyəvi analiz metodları ilə kobalt, dəmir, kalsium, manqan və maqneziumun oksidlərinin ammonium xloridlə qarş1lıqlı təsirdə olaraq ammonium xlorid kompleksləri əmələ gətirərək, termiki ardıcıllıqla sadə xloridlərə parçalandığı sübut edilmişdir. Kobaltın optimal çıxımı $300^{\circ} \mathrm{C}$ temperaturda 160 dəq müddətində 94\% təşkil edir. Prosesin mexanizminin açılması üçün termoqravimetrik və rentgenfaza analiz metodlarının nəticələrindən istifadə edilmişdir. Kobaltlı birləşmələrin ammonium xloridlə xlorlaşmasının sərbəst enerjilərinin qiymətləri hesablanmışdır. Gibbs enerjisinin qiymətinin temperaturdan asılı olaraq dəyişməsinin hesablanmış qiymətləri verilmiş̧ir. Hesablamalardan da göründüyü kimi $\mathrm{CoCl}_{2}$ birləşməsinin alınması termodinamiki cəhətdən mümkündür.Alınmış məhlullardan kobaltın və onu müşayət edən elementlərin pH-dan asılı olaraq çökdürülərək bir-birindən ayrılma şəraiti öyrənilmişdir.

Açar sözlar: kobalt, ammonium xlorid, filiz, sarbast enerji,termodinamiki,çökdürmə.

\section{ТЕРМОДИНАМИЧЕСКИЕ ПОКАЗАТЕЛИ ПРОЦЕССА ПЕРЕРАБОТКИ КОБАЛЬТСОДЕРЖАЩИХ РУД И ИССЛЕДОВАНИЕ УСЛОВИЙ ВЫДЕЛЕНИЯ КОБАЛЬТА ИЗ РАСТВОРА}

\section{Н.В.Юсифова}

Исследована кинетика выделения кобальта методом растворения из кобальтсодержащих руд. С помощью химических методов анализа доказано, что оксиды кобальта, железа, кальция, марганца и магния, образуя комплексы при взаимодействии с хлористым аммонием, последовательно термически разлагаются на простые хлориды. Оптимальный выход кобальта составляет $94 \%$ при $300^{\circ} \mathrm{C}$ и 160 мин. Для установления механизма процесса использованы результаты термогравиметрического и рентгенофазового методов анализа. Рассчитаны значения свободной энергии хлорирования соединений кобальта хлористым аммонием. Приведены также рассчитанные значения изменения энергии Гиббса в зависимости от температуры. Показано, что получение хлорида кобальта термодинамически возможно. Исследованы условия осаждения и отделения кобальта от сопутствующих его элементов в зависимости от $\mathrm{pH}$ растворов.

Ключевые слова: кобальт, хлористый аммоний, руда, свободная энергия, термодинамика, осаждение. 